\title{
Застосування фізичної радіомодифікації в неоад’ювантному лікуванні раку прямої кишки
}

\begin{abstract}
Мета роботи: вивчення ефективності радіомодифікації локальним низькочастотним магнітним полем (РЛнМП) в неоад’ювантній променевій терапії раку прямої кишки.

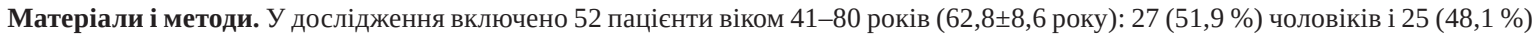
жінок. Дизайн дослідження передбачав проведення дослідження проліферативної активності (Кі-67) в аденокарциномах прямої кишки, подальшу неоад’ювантну променеву терапію (НПТ) сумарною вогнищевою дозою (СВД) 20-25 Гр (4-5 сеансів по 5 Гр) із застосуванням фізичного радіомодифікатора (локального низькочастотного магнітного поля), після завершення якої повторно досліджували проліферативну активність (Ki-67) в аденокарциномах та проводили оперативне лікування відповідно. Результати досліджень та їх обговорення. Експресія Кi-67 в аденокарциномах прямої кишки до НПТ та радіомодифікації локальним низькочастотним магнітним полем становила $(25,3 \pm 9,07) \%$, після НПТ та радіомодифікації - $(15,5 \pm 5,9) \%(\mathrm{p}<0,05)$. Таким чином, експресія Кі-67 в аденокарциномах прямої кишки знизилась на 9,8 \%. У пацієнтів із ступенем диференціації аденокарциноми прямої кишки G2 (n=43) індекс Кi-67 до НПТ і РЛНМП становив $(24,8 \pm 9,4) \%$, а в пацієнтів із ступенем диференціації G3 (n=9) до НПТ і РЛНМП становив $(27,6 \pm 9,4)$ \% (p>0,05). Після проведення НПТ і РЛНМП у пацієнтів з G2 (n=48) індекс Кi-67 становив $(15,0 \pm 5,5) \%$, а в пацієнтів з G3 (n=4) Ki-67 становив $(22,2 \pm 8,4) \%(p=0,01)$. Спостерігали суттєву різницю в зниженні відсотка проліферативної активності в підгрупах пацієнтів із помірно диференційованими (G2) та низькодиференційованими аденокарциномами (G3) після завершення НПТ і РЛНМП.

Індекс Ki-67 (n=43) G2 після НПТ і РЛНМП знизився на 9,3 \%, а індекс Ki-67 (n=4) G3 після НПТ і РЛНМП знизився на 5,4 \%. Однак варто зауважити, що у 5 пацієнтів на фоні НПТ і РЛНМП ступінь диференціації з G3 змінився на G2.

Між рівнем експресії Кі-67 до початку лікування та експресією Кі-67 на фоні НПТ і РЛНМП спостерігали помірний кореляційний зв’язок індексу проліферації $(\mathrm{r}=0,6 ; \mathrm{p}<0,05)$.

В аденокарциномах прямої кишки пацієнтів похилого і старечого віку $(\mathrm{n}=33)$ і пацієнтів середнього віку $(\mathrm{n}=19)$ iндекс проліферативної активності був практично однаковий $(24,9 \pm 8,0) \%$ і $(26,0 \pm 10,8)$ \% відповідно. Середнє значення Кi-67 в аденокарциномах прямої кишки після завершення НПТ і РЛНМП у вікових підгрупах становило $(16,0 \pm 5,8) \%(\mathrm{n}=33)$ i $(14,3 \pm 6,1)$ \% (n=19) відповідно. Індекс проліферації аденокарцином у пацієнтів середнього віку знизився на 11,7 \%, а у пацієнтів похилого і старечого віку - на 8,9 \% $(\mathrm{p}<0,05)$.
\end{abstract}

Ключові слова: рак прямої кишки; променева терапія; низькочастотне магнітне поле; Ki-67.

Постановка проблеми і аналіз останніх досліджень та публікацій. Променева терапія раку прямої кишки є ефективним, науково обгрунтованим методом протипухлинної дії, яка інтегрує досягнення експериментальної і клінічної онкології, радіобіології, фізики та можливості гамма-терапевтичного обладнання. В той же час, можливості променевої терапії раку прямої кишки обмежені низькою толерантністю навколишніх органів і тканин до опромінення, а також ризиком індукції негативних реакції з боку організму в цілому. Ця обставина є основою для пошуку способів і засобів, які б сприяли підвищенню радіочутливості пухлини прямої кишки.

Для оцінки лікувального патоморфозу i об'єктивного аналізу відповіді на лікування в онкології на сьогодні існує ряд методів, серед яких морфологічні (гістологічний тип пухлини, ступінь диференціації, судинна інвазія та ін.), імуногістохімічні (тимідин синтетаза (TS), тимідин фосфорилаза, дигідропіримідин дегідрогеназа (DYPD), ERCC-1, топоізомераза II-альфа, Ki-67). Детально розглянемо маркери проліферативної активності Ki-67.
Проліфераціяпухлинних клітин-ценевід'ємна частина злоякісних пухлин і часто пов'язана з їі агресивністю. Білок Кі-67 експресується з G1 по М фазу клітинного циклу, з його допомогою можна оцінювати проліферуючий пул клітин, на який впливає канцероцидний/канцеростатичний фактор [1]. Ki-67 - ядерний білок, пов'язаний з проліферацією клітин, кодується МКI67 геном, локалізується на 10 хромосомі (10q25-qter). Ki-67 вперше в 1983 році на клітинній лінії, отриманій із лімфоми Ходжкіна, був описаний Gerdes та співавт. Оскільки Кі-67 виявляється лише в клітинах, які діляться, став широко застосовуватись як маркер проліферації [2]. За результатами ряду досліджень [1, 3] встановлено, що Ki-67 життєво необхідний в мітозі клітини, а при його нейтралізації мітоз клітини зупиняється.

Мета роботи: вивчити ефективність радіомодифікації локальним низькочастотним магнітним полем у неоадювантній променевій терапії раку прямої кишки залежно від ступеня диференціації аденокарциноми прямої кишки та віку пацієнтів. 
Матеріали та методи. В основу контрольованого проспективного одноцентрового дослідження покладено вивчення ефективності підсилення протипухлинного ефекту променевої терапії раку прямої кишки фізичним радіомодифікатором у хворих на рак середньо- та нижньоампулярного відділів прямої кишки II-III стадій (T1-4 N0-2 M0), які перебували на стаціонарному лікуванні клінічних баз кафедри хірургії факультету післядипломної освіти Вінницького національного медичного університету імені М. І. Пирогова.

Дослідженням передбачено:

1. Інформована добровільна згода на проведення діагностики, лікування, операції та знеболення у хворого на рак середньо- та нижньоампулярного відділів прямої кишки.

2. Морфологічна верифікація аденокарциноми прямої кишки.

3. Стадія онкологічного захворювання (Т1-4 N0-2 M0).

4. Загальний стан пацієнта за ECOG 0-2.

5. Супутні захворювання в стадії компенсації.

Дослідженням не передбачено:

1. Загальний стан пацієнта за ECOG 3 - 4.

2. Синхронний та метахронний рак.

3. Супутні захворювання в стадії субкомпенсації та декомпенсації.

У дослідження було включено 52 пацієнти віком 41-80 років (62,8 $\pm 8,6$ року): 27 (51,9 \%) чоловіків і 25 (48,1 \%) жінок. Дана група пацієнтів за віковими і статевими ознаками мало відрізнялась від середніх показників у популяції хворих на РПК в Хмельницькій області.

Дизайн дослідження передбачав проведення дослідження проліферативної активності (Ki-67) в аденокарциномах прямої кишки, подальшу неоадювантну променева терапію (НПТ) сумарною вогнищевою дозою (СВД) 20-25 Гр (4-5 сеансів по 5 Гр) із застосуванням фізичного радіомодифікатора (локального низькочастотного магнітного поля), після завершення якої повторно досліджували проліферативну активність (Кі-67) в аденокарциномах та проводили оперативне лікування відповідно.

Діагноз встановлювали на основі загальноклінічних даних (з оцінкою загального стану пацієнта за ECOG), інструментальних методів (УЗД органів черевної порожнини, малого таза та заочеревинного простору; ректороманоскопія/колоноскопія з біопсією пухлини; спіральна комп'ютерна томографія органів грудної, черевної порожнини та порожнини малого таза з внутрішньовенним контрастуванням) та морфологічного дослідження біопсійного матеріалу.
Імуногістохімічне дослідження проводили за стандартною методикою. Демаскування антигенів проводили шляхом інкубації зрізів у водяній бані “ВБ-4” при температурі 97-98 ${ }^{\circ} \mathrm{C}$ у розчині 0,01 цитратного буфера $(\mathrm{pH}=6,0)$. Ендогенну пероксидазу блокували протягом 10 хв у 3 \% розчині перекису водню. Інкубація з первинними антитілами до Ki-67 (клон MIB-1“Dako”) у розведенні 1:400 тривалістю 20 хв при кімнатній температурі. Реакція антиген-антитіло була візуалізована з використанням системи детекції "UltraVision Quanto Detection System HRP DAB Chromogen" ("Thermo scientific”, США), яка включала блокування ендогенної активності пероксидази перекисом водню, блокування неспецифічного фонового забарвлення з використанням “Ultra V block”, посилення реакції "Primary Antibody Amplifier Quanto" та кінцеву візуалізацію діамінобензидином з дозабарвленням ядер гематоксиліном Маєра. Позитивним результатом імуногістохімічної реакції вважали наявність специфічного забарвлення ядер пухлинних клітин. Індекс Ki-67 визначали за допомогою підрахунку відсотка позитивної реакції у 1000 ракових клітин. Рівень експресії білка Кі-67 оцінювали напівкількісним методом у відсотках.

Дистанційну неоад’ювантну променеву терапію (НПТ) проводили за методикою великого фракціонування у разовій вогнищевій дозі (РВД) 5 Гр СВД 20-25 Гр на гамма-терапевтичних установках АГАТ $\mathrm{P} / \mathrm{P} 1$ з джерелами випромінювання $\mathrm{Co}^{60}$. Хірургічне втручання проводили через 24-48 год.

Локальне низькочастотне магнітне поле створювали за допомогою портативного апарата МАГ 30-4, який розташовували в крижово-куприковій ділянці. Максимальна локальна магнітна індукція в ділянці

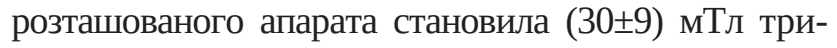
валістю 18-20 хв. Радіомодифікатор застосовували безпосередньо перед кожним сеансом гамматерапії.

Статистичний аналіз отриманих даних проводили за допомогою статистичної прикладної програми STATISTICA 10 (StatSoft Inc., США). Для аналізу статистично значущих відмінностей у випадку нормального розподілу використовували параметричний критерій Ст’юдента. Для отримання коефіцієнта кореляції використовували метод Пірсона. Результати наведені у вигляді середнього значення показників і стандартного відхилення (M $\pm \sigma$, де $\mathrm{M}$ - середнє арифметичне, $\sigma$ - середнє відхилення). Відмінність вважали вагомою при $\mathrm{p} \leq 0,05$.

Результати досліджень та їх обговорення. При первинній біопсії у 82,6 \% (n=43) па- 
цієнтів діагностовано помірно диференційовану G2 аденокарциному прямої кишки, у 17,4 \% $(\mathrm{n}=9)$ - низькодиференційовану G3 аденокарциному. Диференціація аденокарцином після завершення дистанційної НПТ та РЛНМП суттево не змінилась і становила G2 у 92,3 \% $(\mathrm{n}=48)$ та G3 у 7,7 \% $(n=4)(p=0,001)$ пацієнтів. Однак у 9,7 \% (n=5) пацієнтів спостерігали морфологічний регрес, при якому морфологічні зміни вказували на підвищення диференціації аденокарцином прямої кишки на тлі дистанційної НПТ та радіомодифікації.

Експресія Ki-67 в аденокарциномах прямої кишки до НПТ та радіомодифікації локальним низькочастотним магнітним полем становила $(25,3 \pm 9,07) \%$, після НПТ та радіомодифікації становила $(15,5 \pm 5,9) \%(\mathrm{p}<0,05)$. Таким чином, експресія Кi-67 в аденокарциномах прямої кишки знизилась на 9,8 \% (рис. 1).

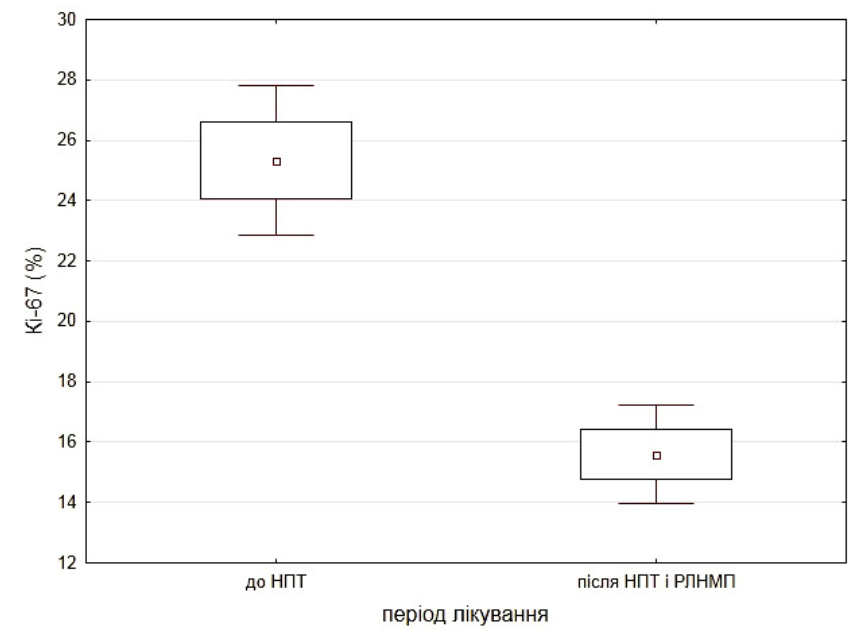

Рис. 1. Показники Кi-67 (\%) аденокарцином прямої кишки на етапі до неоад’ювантної променевої терапії та після неоад’ювантної променевої терапії і радіомодифікації локальним низькочастотним магнітним полем.

У пацієнтів зі ступенем диференціації аденокарциноми прямої кишки G2 (n=43) індекс Ki-67 до НПТ і РЛНМП становив $(24,8 \pm 9,4) \%$, а в пацієнтів із ступенем диференціації G3 (n=9) до НПТ і РЛНМП - $(27,6 \pm 9,4) \%$ (p>0,05). Після проведення НПТ і РЛНМП у пацієнтів з $\mathrm{G} 2(\mathrm{n}=48)$ індекс Ki-67 становив $(15,0 \pm 5,5) \%$, а в пацієнтів 3 G3 $(\mathrm{n}=4) \mathrm{Ki}-67-(22,2 \pm 8,4) \%(\mathrm{p}=0,01)$. Виявлено суттєву різницю в зниженні відсотка проліферативної активності в підгрупах пацієнтів із помірнодиференційованими (G2) та низькодиференційованими аденокарциномами (G3) після завершення НПТ і РЛНМП (рис. 2).
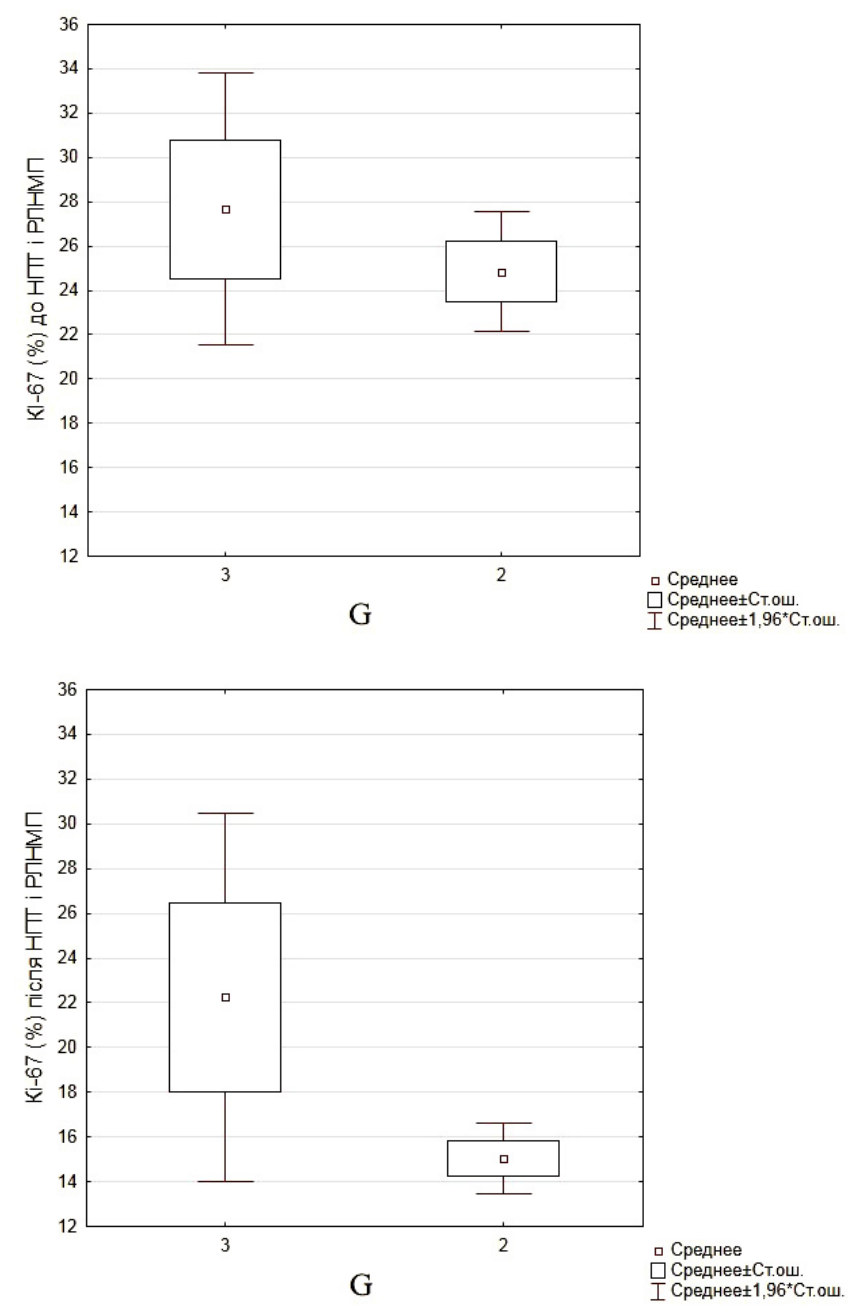

Рис. 2. Показники Ki-67 (\%) аденокарцином прямої кишки залежно від ступеня диференціації (G) на етапі до неоад’ювантної променевої терапії та після неоад’ювантної променевої терапії і радіомодифікації локальним низькочастотним магнітним полем.

Індекс Ki-67 (n=43) G2 після НПТ і РЛНМП знизився на 9,3 \%, а індекс Ki-67 (n=4) G3 після НПТ і РЛНМП знизився на 5,4 \%. Однак варто зауважити, що у 5 пацієнтів на фоні НПТ і РЛНМП ступінь диференціації з G3 змінився на G2.

Між рівнем експресії Кі-67 до початку лікування та експресією Кi-67 на фоні НПТ і РЛНМП спостерігали помірний кореляційний зв'язок індексу проліферації (r=0,6; p<0,05) (рис. 3).

В аденокарциномах прямої кишки пацієнтів похилого і старечого віку (n=33) і пацієнтів середнього віку (n=19) індекс проліферативної активності був практично однаковим $(24,9 \pm 8,0) \%$ і $(26,0 \pm 10,8)$ \% відповідно. Середнє значення Ki-67 в аденокарциномах прямої кишки після завершення НПТ і РЛНМП у вікових підгрупах становило $(16,0 \pm 5,8) \%(n=33)$ і $(14,3 \pm 6,1) \%(n=19)$ відповідно. 


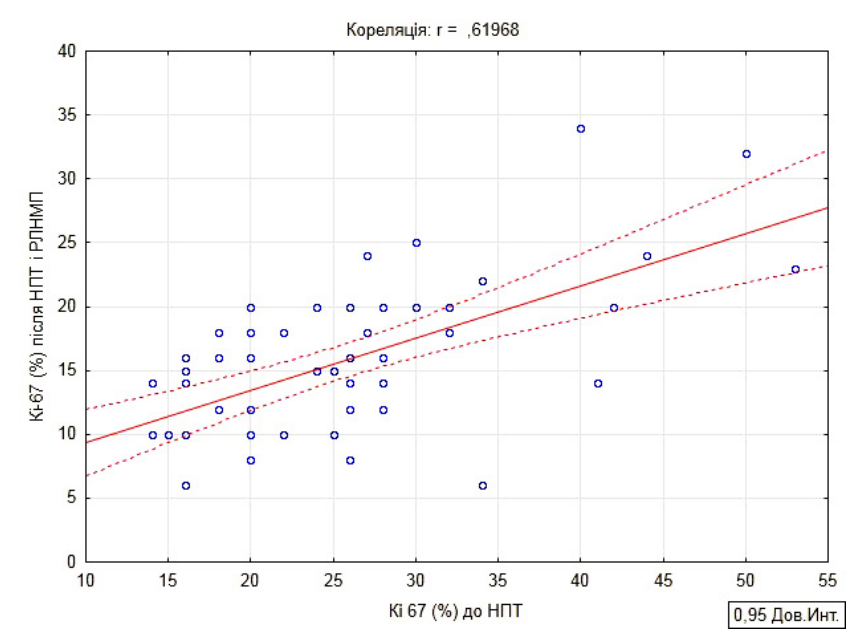

Рис. 3. Кореляційний зв’язок між неоад’ювантною променевою терапією з радіомодифікацією локальним низькочастотним магнітним полем та експресією Кi-67 $(\mathrm{r}=0,6 ; \mathrm{p}<0,05)$.

Індекс проліферації аденокарцином у пацієнтів середнього віку знизився на $11,7 \%$, а у пацієнтів похилого і старечого віку - на 8,9 \% $(\mathrm{p}<0,05)$ (рис. 4).

Статистично достовірного зв’язку ( $\mathrm{p}=0,1)$ між рівнем Кi-67 і стадією аденокарциноми прямої кишки не встановлено.

Висновки. 1. Експресія Кі-67 в аденокарциномах прямої кишки після неоад’ювантної променевої терапії та радіомодифікації локальним низькочастотним магнітним полем достовірно знизилась на 9,8 \%: у пацієнтів з G2 - на 9,3 \%, а у пацієнтів 3 G3 - на 5,4 \%; у пацієнтів середнього віку на $11,7 \%$, а у пацієнтів похилого і старечого віку - на 8,9\%.

\section{СПИСОК ЛІТЕРАТУРИ}

1. The murine Ki-67 cell proliferation antigen accumulates in the nucleolar and heterochromatic regions of interphase cells and at the periphery of the mitotic chromosomes in a process essential for cell cycle progression / M. Starborg, K. Gell, E. Brundell, C. Höög // Journal of Cell Science. - 1996. - Vol. 109. - P. 143-153. 2. Gardes J. Ki-67 and other proliferation markers useful for immunohistological diagnostic and prognostic evaluations in

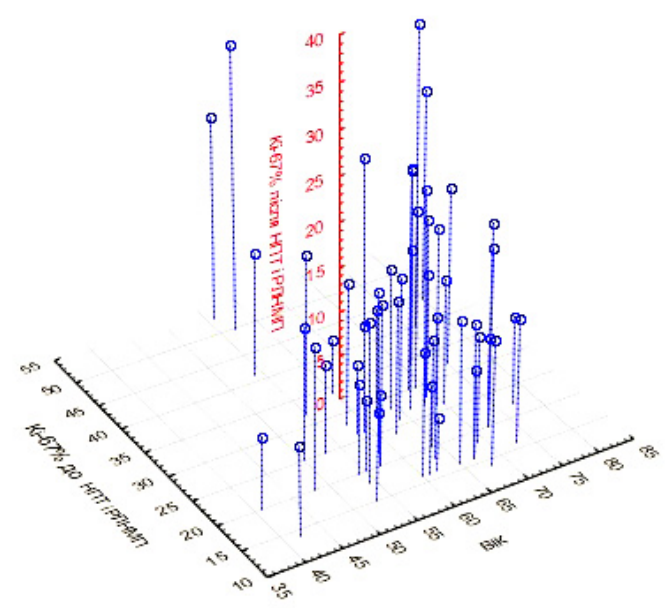

Рис. 4. Ki-67 (\%) аденокарцином прямої кишки залежно від вікових груп (середній вік <60 років, похилий і старечий вік >60 років) до етапу неоад’ювантної променевої терапії (НПТ) та після неоад’ювантної променевої терапії з радіомодифікацією локальним низькочастотним магнітним полем.

2. Між рівнем експресії Ki-67 до початку лікування та експресією Кі-67 на тлі НПТ і РЛНМП встановлено помірний кореляційний зв'язок індексу проліферації. Статистично достовірного зв’язку між рівнем Ki-67 і стадією аденокарциноми прямої кишки не виявлено.

Перспективи подальших досліджень. За даними дослідження локальне низькочастотне магнітне поле на фоні променевої терапії є ефективним чинником, який сприяє морфологічній та імуногістохімічній регресії аденокарциноми прямої кишки. Проведене дослідження у подальшому може бути основою для впровадження радіомодифікаторів та полірадіомодифікаторів у клінічні протоколи неоад’ювантного лікування раку прямої кишки.

human malignancies / J. Gardes // Seminars in Cancer Biology. 1990. - Vol. 1. - P. 99-106.

3. The cell proliferation-associated antigen of antibody Ki-67: a very large, ubiquitous nuclear protein with numerous repeated elements, representing a new kind of cell cycle-maintaining proteins / C. Schlüter, M. Duchrow, C. Wohlenberg [et al.] // The Journal of Cell Biology. - 1993. - Vol. 3. - P. 513-522.

\section{REFERENCES}

1. Starborg, M., Gell, K., Brundell, E., \& Höög, C. (1996). The murine Ki-67 cell proliferation antigen accumulates in the nucleolar and heterochromatic regions of interphase cells and at the periphery of the mitotic chromosomes in a process essential for cell cycle progression. Journal of Cell Science, 109, 143-153.
2. Gardes, J. (1990). Ki-67 and other proliferation markers useful for immunohistological diagnostic and prognostic evaluations in human malignancies. Seminars in Cancer Biology, 1, 99-106.

3. Schlüter, C., Duchrow, M., Wohlenberg, C., Becker, M.H., Key, G., Flad, H.D., \& Gerdes, J. (1993). The cell proliferation- 
associated antigen of antibody Ki-67: a very large, ubiquitous nuclear protein with numerous repeated elements, representing a new kind of cell cycle-maintaining proteins. The Journal of Cell Biology, 3, 513-522. .

Отримано 02.10.2019

Електронна адреса для листування: kernychniy.vv@gmail.com

V. V. KERNYCHNYI, A. I. SUKHODOLIA, O. O. PIDMURNIAK, S. A. SUKHODOLIA

M. Pyrohov Vinnytsia Memorial Medical University

\title{
APPLICATION OF PHYSICAL RADIOMODIFICATION IN NEOADJUVANT THERAPY OF RECTAL CANCER
}

\begin{abstract}
The aim of the work: investigation of effective radiomodification by the local low-frequency magnetic field in the neadjuvant therapy for rectum cancer.

Materials and Methods. An investigation included 52 patients aged 41-80 years old (62.8 \pm 8.6 ): 27 (51.9 \%) men and 25 (48.1\%) women. The design of study is to conduct the searching of proliferate activity (Ki-67) in adenocarcinoma of the rectum and further neoadjuvant radiation therapy (NRT), total focal dose (TFD) 20-25 g (4-5 sessions to $5 \mathrm{~g}$ ) using physical radio-modificatior (local lowfrequency magnetic field). Later it was second study of proliferation activity (Ki-67) in adenocarcinomas and also surgery.

Results and Discussion. The expression of Ki-67 in the adenocarcinomas of the rectum to NRT and radiomodification by the local lowfrequency magnetic field (RLLMF) was $(15.5 \pm 5.9) \%(p<0.05)$. Thus expression of Ki-67 in adenocarcinomas of the rectum decreased by $9.8 \%$. An index Ki-67 to NRT and RLLMF of the patients that have the degree differentiation of adenocarcinomas of the rectum G2 $(\mathrm{n}=43)$ was $(24.8 \pm 9.4) \%$. The index of the patients that have the degree differentiation G3 $(\mathrm{n}=9)$ to NRT and RLLMF was $(27.6 \pm 9.4) \%$ (p>0.05). After NRT and RLLMF the patients of G2 (n=48) have Ki-67 of (15.0+-5.5) \%. But the patients of G3 (n=4) have Ki-67 of $(22.2 \pm 8.4) \%(p=0.01)$. There was a significant difference in reducing the percantage of proliferation activity in subgroups of patients with moderately differentiated (G2) and low-differentiated adenocarcinoma (G3) after NRT and RLLMF.

Ki-67 index (n=43) G2 after NRT and RLLMF decreased by $9.3 \%$ but index Ki-67 (n=4) G3 after NRT and RLLMF decreased by $5.4 \%$. However it should be noted that degree differentiation in 5 patients from G3 has changed to G2.

It was noted the moderate correlation of proliferation index from the expression level of Ki-67 till the treatment beginning and the expression of Ki-67 against a background of NRT and RLLMF $(r=0,6 ; \mathrm{p}<0,05)$.

Index of proliferation activity in the adenocarcinomas of the rectum of the old age and elderly patients $(\mathrm{n}=19)$ was almost equal (24.9 \pm 8.0$) \%$ and $(26.0 \pm 10.8) \%$. After the end of NRT and RLLMF the average value of Ki- 67 in the adenocarcinomas of the rectum of age subgroups was $(16.0 \pm 5.8) \%(n=33)$ and $(14.3 \pm 6.1) \%(n=19)$. Proliferation index of adenocarcinomas of the middle-aged patients decreased by $11.7 \%$ but it was by $8.9 \%(\mathrm{p}<0.05)$ of the old age and elderly patients.
\end{abstract}

Key words: rectal cancer; radiation therapy; low-frequency magnetic field; Ki-67.

В. В. КЕРНИЧНЫЙ, А. И. СУХОДОЛЯ, А. А. ПИДМУРНЯК, С. А. СУХОДОЛЯ

Винницкий национальный медицинский университет имени Н. И. Пирогова

\section{ПРРМЕНЕНИЕ ФИЗИЧЕСКОЙ РАДИОМОДИФИКАЦИИ В НЕОАДЬЮВАНТНОМ ЛЕЧЕНИИ РАКА ПІРЯМОЙ КИІІКИ}

\footnotetext{
Цель работы: изучение эффективности радиомодификации локальным низкочастотным магнитным полем (РЛНМП) в неоадъювантной лучевой терапии рака прямой кишки в зависимости от степени дифференциации аденокарциномы прямой кишки и возраста пациентов.

Материалы и методы. В исследование было включено 52 пациента в возрасте 41-80 лет (62,8 „8,6 лет): 27 (51,9 \%) мужчин и 25 (48,1 \%) женщин.

Дизайн исследования предусматривал проведение исследования пролиферативной активности (Ки-67) в аденокарциномах прямой кишки, дальнейшую неоадъювантную лучевую терапию (НЛТ) суммарной очаговой дозой (СВД) 20-25 Гр (4-5 сеансов по 5 Гр) с применением физического радиомодификатора (локальное низкочастотное магнитное поле), после завершения которой повторно исследовали пролиферативную активность (Ки-67) в аденокарциномах и проводили оперативное лечение соответственно.

Результаты исследований и их обсуждения. Экспрессия Ки-67 в аденокарциномах прямой кишки до НЛТ и радиомодификации локальным низкочастотным магнитным полем составляла $(25,3 \pm 9,07)$ \%, после НлТ и радиомодификации составила $(15,5 \pm 5,9)$ \% ( $<0,05)$. Таким образом, экспрессия Ки-67 в аденокарциномах прямой кишки снизилась на 9,8 \%. У пациентов со степенью дифференциации аденокарциномы прямой кишки G2 (n=43) индекс Ки-67 до НЛТ и РЛНМП (радиомодификации локальным низкочастотным магнитным полем) составил $(24,8 \pm 9,4) \%$, а у пациентов со степенью дифференциации G3 (n=9) до НЛТ и РЛНМП составил $(27,6 \pm 9,4)$ \% (p>0,05). После проведения НЛТ и РЛНМП у пациентов с $\mathrm{G} 2$ (n=48) индекс Ки-67 составил $(15,0 \pm 5,5) \%$, а у пациентов с G3 $(n=4)$ Ки-67 составил $(22,2 \pm 8,4) \%(p=0,01)$. Отмечено существенное различие в снижении процента пролиферативной активности в подгруппах пациентов с умеренно-дифференцированной (G2) и низкодифференцированной аденокарциномой (G3) после завершения НЛТ и РЛНМП.
} 


\section{З ДОСВІДУ РОБОТИ}

Индекс Ки-67 (n=43) G2 после НЛТ и РЛНМП снизился на 9,3 \%, а индекс Ки-67 (n=4) G3 после НЛТ и РЛНМП снизился на 5,4 \%. Однако стоит заметить, что у 5 пациентов на фоне НЛТ и РЛНМП степень дифференциации G3 изменилась на G2.

Между уровнем экспрессии Ки-67 до начала лечения и экспрессией Ки-67 на фоне НЛТ и РЛНМП отмечена умеренная корреляционная связь индекса пролиферации ( $\mathrm{r}=0,6 ; \mathrm{p}<0,05)$.

В аденокарциномах прямой кишки пациентов пожилого и старческого возраста $(\mathrm{n}=33)$ и пациентов среднего возраста $(\mathrm{n}=19)$ индекс пролиферативной активности был практически одинаковым $(24,9 \pm 8,0) \%$ и $(26,0 \pm 10,8) \%$ соответственно. Среднее значение Ки-67 в аденокарциномах прямой кишки после завершения НЛТ и РЛНМП в возрастных подгруппах составило $(16,0 \pm 5,8) \%(\mathrm{n}=33)$ и $(14,3 \pm 6,1) \%(\mathrm{n}=19)$ соответственно. Индекс пролиферации аденокарцином у пациентов среднего возраста снизился на 11,7 \%, а у пациентов пожилого и старческого возраста на $8,9 \%$ (p<0,05).

Ключевые слова: рак прямой кишки; лучевая терапия; низкочастотное магнитное поле; Ки-67. 